\title{
EXPLORING THE ROLE OF MALAYSIAN RESEARCH UNIVERSITY- BASED INCUBATORS IN FACILITATING THE ENTREPRENEURIAL PROCESS
}

\author{
EXPLORANDO O PAPEL DAS INCUBADORAS UNIVERSITÁRIAS DE PESQUISA DA \\ MALÁSIA NA FACILITAÇÃO DO PROCESSO EMPRESARIAL \\ EXPLORANDO EL PAPEL DE LAS INCUBADORAS DE NEGOCIOS DE LAS \\ UNIVERSIDADES INVESTIGADORAS MALASIAS EN EL FA VORECIMIENTO DEL \\ PROCESO EMPRENDEDOR
}

\author{
Guat Eng Liow ${ }^{1}$ \\ (iD) Hui Man Wong ${ }^{2}$
}

\section{Cite as - American Psychological Association (APA)}

Liow, G. E., \& Wong, H. M. (2021, May/Aug.). Exploring the role of Malaysian research university-based incubators in facilitating the entrepreneurial process. International Journal of Innovation - IJI, São Paulo, 9(2), 239-266. https://doi.org/10.5585/iji.v9i2.18578.

\begin{abstract}
Objective of the study: To clarify the role of university-based incubators in facilitating the entrepreneurial process by elucidating the value-add of the incubation activities through the lens of real options-driven theory and resource-based view theory.

Methodology/approach: An in-depth case study of five Malaysian research-led universities is conducted through thirteen semi-structured interviews with UBI managers and staff.

Originality/Relevance: Integrating real options-driven theory and resource-based view to understand the roles of UBI in supporting the entrepreneurial process, elaborated in the three stages of incubation: pre-main-post incubation phase.

Main results: UBI has a decisive role in facilitating entrepreneurial process through selecting potential entrepreneurs, mobilising the optimal mix of tangible and intangible resources, and monitoring the entrepreneurial process. All the five UBIs displayed interorganisational relationships with the various stakeholders and have capable incubator manager as a linchpin to facilitate the incubation process from pre to main incubation phase. However, there is little evidence on aftercare post incubation services to support the entrepreneurial growth stage, which are crucial for their continuing survival and growth.

Theoretical/methodological contributions: It adopts a multi-theoretical lens of real options-driven theory and resource-based view theory to explain the roles of UBIs in the entrepreneurial process.

Social/management contributions: It provides insights, best practices, and frameworks regarding the incubation process of Malaysian UBIs, and how its roles can be enhanced to drive more successful entrepreneurial processes.
\end{abstract}

Keywords: University-based incubators. Incubation process. Academic entrepreneurship.

\footnotetext{
1 Doctor of Business Administration (DBA). HELP University. Kuala Lumpur, Malaysia. wendy.liow@ help.edu.my

2 Master of Philosophy (MPhil). HELP University. Kuala Lumpur, Malaysia. elaine9393@gmail.com
} 


\section{Resumo}

Objetivo do estudo: Esclarecer o papel das incubadoras universitárias de pesquisa na facilitação do processo empresarial, elucidando o valor agregado das atividades de incubação através das lentes da teoria das opções reais e da teoria da visão baseada em recursos.

Metodologia / abordagem: Uns estudos de caso aprofundado de cinco universidades da Malásia lideradas por pesquisas é conduzido por meio de 13 entrevistas semiestruturadas com gerentes e funcionários das Incubadoras de base universitária.

Originalidade / Relevância: Integrar a teoria das opções reais e a visão baseada em recursos para compreender o papel das incubadoras de base universitárias no apoio ao processo empresarial, elaborado nas três fases de incubação: fase pré-central-pós-incubação.

Resultados principais: Incubadoras de base universitárias tem um papel decisivo na facilitação do processo empresarial por meio da seleção de potenciais empresarial, mobilizando a combinação ideal de recursos tangíveis e intangíveis e monitorando o processo empresarial. Todas as cinco incubadoras de base universitárias apresentam relações intraorganizacionais com os diversos públicos e têm um gerente de incubadora capacitado como eixo para facilitar o processo de incubação da fase pré à incubação principal. No entanto, há poucas evidências sobre os serviços pós-incubação pós-atendimento para apoiar o estágio de crescimento empresarial, que são cruciais para sua sobrevivência e crescimento contínuos.

Contribuições teóricas / metodológicas: Ele adota uma lente multi-teórica da teoria baseada em opções reais e teoria da visão baseada em recursos para explicar os papéis das incubadoras de base universitárias no processo empresarial.

Contribuições sociais / de gestão: Ele fornece entendimento, melhores práticas e estrutura sobre o processo de incubação de incubadoras de base universitárias da Malásia e como suas funções podem ser aprimoradas para impulsionar um processo empresarial mais bem-sucedido.

Palavras-chave: Incubadoras de base universitária. Processo de incubação. Empresarialismo acadêmico.

\section{Resumen}

Objetivo de la investigación: Esclarecer el papel de las incubadoras empresariales en las universidades investigadoras en el favorecimiento del proceso emprendedor, a través de la explicación del valor añadido de las actividades incubación, por medio de la teoría de las opciones reales y de la visión basada en los recursos.

Metodología: A través de trece entrevistas semiestructuradas con el personal y la administración de las incubadoras universitarias se ha llevado a cabo un estudio de caso en profundidad de cinco universidades investigadoras malasias.

Originalidad/Relevancia: Integrar la teoría de la las opciones reales y la visión basada en los resultados para comprender los roles de las incubadoras universitarias en el apoyo a los procesos de emprendimiento, elaborada en las tres fases del proceso de incubación: la pre incubación, la incubación y la fase de post-incubación.

Resultados: Las incubadoras universitarias tienen un papel decisivo a la hora de facilitar los procesos de emprendimiento a través de la selección de emprendedores potenciales, de la movilización de recursos óptimos, tanto tangibles como intangible y del monitoreo del proceso de emprendimiento. Las cinco incubadoras universitarias estudiadas demostraron tener relaciones inter-organizativas con las diferentes partes interesadas y contaban con un gerente capacitado para actuar como eje facilitador durante el proceso de incubación desde la fase de pre-incubación hasta la fase incubación. Sin embargo, hay poca evidencia sobre el proceso de seguimiento post-incubación encaminado a apoyar la etapa de crecimiento empresarial, siendo esta una fase crucial para la continuación, supervivencia y crecimiento. Contribución teórico-metodológica: Se adopta un enfoque multi-teórico de una teoría guiada por las opciones reales y de la visión basada en recursos para explicar los roles de las incubadoras universitarias en los procesos de emprendimiento. 
Contribuciones sociales y de gestión: Proporciona perspectivas, mejores prácticas y un marco con respecto al proceso de incubación en las incubadoras universitarias malasias, y cómo el papel de estas puede ser mejorado para conducir a unos procesos de emprendimiento más satisfactorios.

Palabras-clave: Incubadoras universitarias. Proceso de incubación. Emprendimiento académico.

\section{Introduction}

A University is described as a "natural incubator" (Etzkowitz, 2003, p. 111), a cradle specially set up to provide a support structure to kick-start and create new ventures. It is expected to position itself as an entrepreneurial university to actively engage in "Third Mission" activities such as licensing, spin-off, and knowledge transfer (Johnstone \& Huggins, 2016; Larty, Jack, \& Lockett, 2016). University-based incubators (UBIs) play an intermediate and supportive role to provide various services and resources to speed up the commercialisation of research output. They help universities to rethink their place in preparing the next generation of entrepreneurs and creating entrepreneurial environments that facilitate connections and spin out new, knowledge-based ventures. They leverage on existing university resources to provide physical facilities, business support services such as IP management, legal support, as well as access to funding sources and networking to reduce the mortality rate of new ventures. According to Silva and Andrade (2012), UBIs can be conceptualised as an entrepreneurial firm, a laboratory, and storehouse that manages the entrepreneurial process of the incubated firms, infusing these firms with resources, and fostering their success. Therefore, we can expect UBI to be at the vanguard of the entrepreneurial university and has a decisive role in the entrepreneurial system to link talent, technology and capital (Al-Mubaraki \& Busler, 2013).

Various studies reported that a business incubation provides one of the most effective strategies to promote community entrepreneurship (Mahmood et al., 2016; Mahmood, Jamil, \& Yasir, 2017), and assist entrepreneurs in early stages of the business development. However, majority of the studies reviewed focused on the outcome of the business incubation process such as the number of graduated firms or the number of patents, and do not fully explain the role of the incubators in facilitating entrepreneurship. The value of the incubator's role in the entrepreneurial process is continually debated (Peters, Rice, \& Sundararajan, 2004), and there are no conclusive findings that firms supported by incubators have increased chances to succeed compared to firms that have not received the same support (Ratinho, 2011). Beyond the work of Hackett and Ditts (2004a) 'black box' of incubation, very little is known about the role of incubators in supporting the entrepreneurial activities or process, and how they create value other than providing multiple types of services such as assisting in the patenting and licensing 
of inventions (Wright et al., 2009), spin-off (Van Burg, 2014), networking with practitioners (Gordon, Hamilton, \& Jack, 2012), providing ad hoc advice (Perkmann et al., 2013), training and education (Campbell, 1989), as well as low-cost services (Adkins, 1996).

In Malaysia, UBIs are understood as a unique institutional agreement, a government supported tool or an instrument that focuses on developing entrepreneurial culture within the community and initiating a strategic partnership between the academia and the industry. It is tasked to support the transfer of technologies developed in universities to the society, through the creation of spin-offs within the quintuple helix context. However, the role of incubators in supporting the entrepreneurial process is unclear. Scholars such as Peters, Rice, and Sundararajan (2004) attribute the lack of impact to the overemphasis of facilities and administrative services, and not the support services in facilitating the entrepreneurial process. This is echoed by Lalkaka (2002) in an earlier study. He contended that there is a need to "deemphasise low rental and focus on enhanced business services, both for tenants and affiliates on an outreach basis" (p.170) as the key to the success of the new venture. While most of the UBIs in Malaysia provide multiple types of services, the number of firms created by students, alumni or researchers is relatively much lower compared to the more developed countries and UBI remains underutilised. In a report by Global Innovation Index (GII) 2018, Malaysia is ranked $35^{\text {th }}$ in the GII index (Dutta, Lanvin \& Wunsch-Vincent, 2018), suggesting there is relative weaknesses in knowledge, transfer of technology, and technology outputs, which is indicative of the lack of management capability in facilitating the incubation process. Less than $2 \%$ of the more than 27,449 of research outputs were commercialised the last five years (Zaidan, 2014). Among the research universities in Malaysia, UTM ranked the highest in terms of commercialised products with 239, followed by UPM (85), USM (58), and UM (39) since 2000. Hence, it is important to deep dive to understand the softer and broader role of UBI in filling the entrepreneurial skill requirements of the incubatees to support the entrepreneurial process. In view of this, this study attempts to fill the lack of empirical research on the role of UBI and the incubator manager in facilitating the entrepreneurial process.

\section{Literature review}

Incubator-incubation process as an entrepreneurial process

This study extends the theoretical work of Hackett and Ditts (2004a) 'black box' of incubation process. Underpinned by the real options-driven theory (ROT) of incubation, the Hackett \& Ditts (2004a) model explains and predicts how and why each element in the black 
box of business incubation can lead to the development of a new venture. They suggest that an incubator, a "shared office space facility", constantly seeks to provide a strategic, value-added intervention system of monitoring and business assistance to facilitate the successful new venture development and containing the cost of their potential failure. From our review, most of the services offered by UBIs are confined to the provision of a physical structure, a series of training, access to funding, networks, and business support services such as market validation, go-to-market strategy, intellectual property management, and other legal support, characterising the $3^{\text {rd }}$ generation incubator type. Notably, there is very little discussion on measuring the role that UBIs play to enhance the entrepreneurial process towards creating a higher critical mass of viable incubated firms across the different incubation stages.

According to Franco, Haase, and Correia, (2015, p.239). "There is no single model of success factors for a creative incubator, since incubating new undertakings is a highly flexible process, aiming for different objectives". This study draws reference from Hackett \& Dilts (2004a) model which elaborated the four principal elements of the incubation process which includes the selection of incubatees, to being monitored and assisted, and finally infusing the incubatees with resources during their early stage of development and the outcome in terms of the incubatees' survival or failure when they exit the incubator (Figure 1). 


\section{Figure 1}

Hackett \& Dilts (2004a) incubation process model

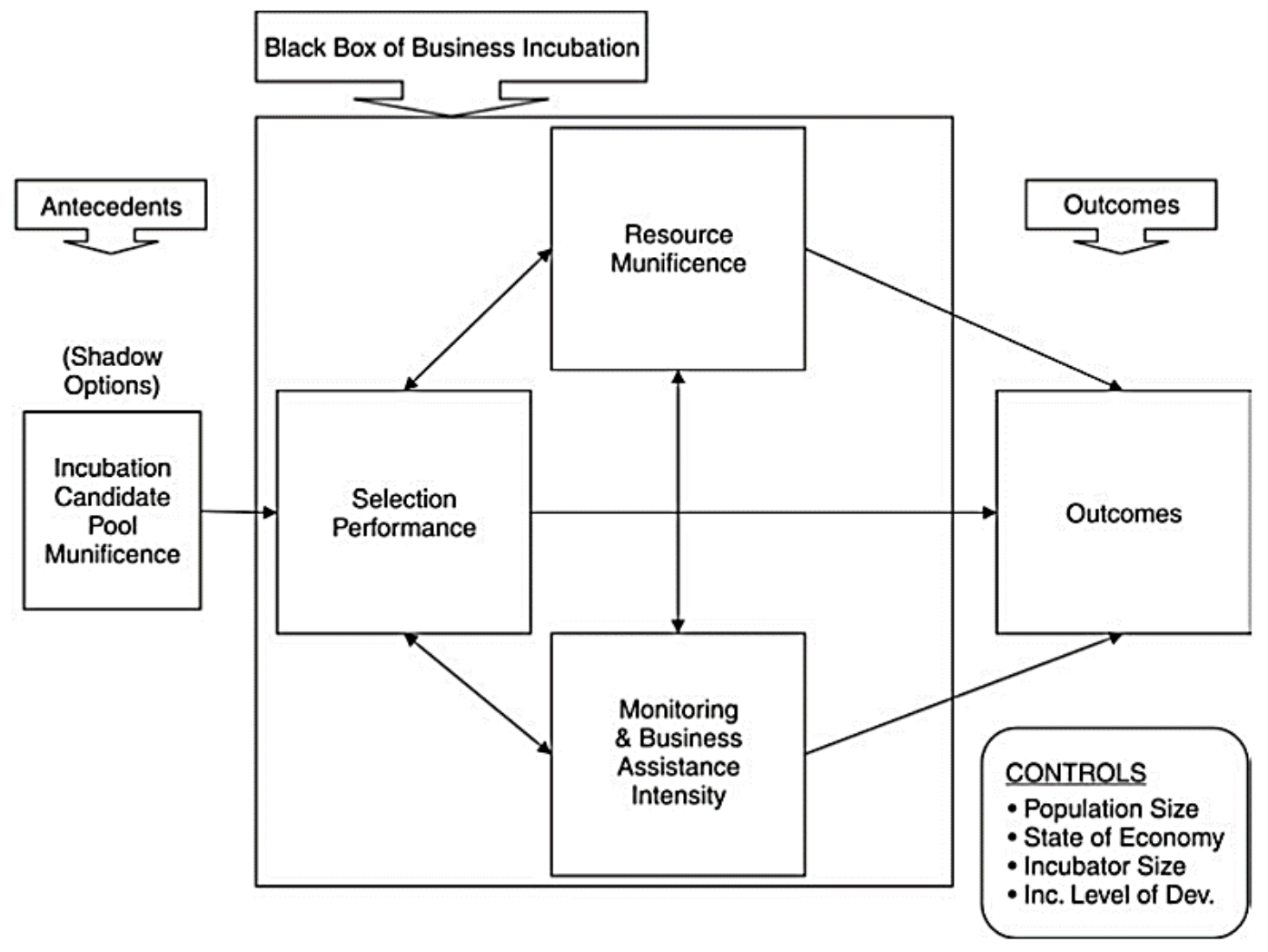

Source: Hackett \& Dilts (2004a).

However, the mere existence of a cost-effective incubator does not in itself be capable to foster the entrepreneurial process in any given setting. An entrepreneurial process is described as the pursuit of market opportunities to create future innovative goods and services discovered, evaluated and exploited to extract social and economic value, leading ultimately to new venture creation (Shane \& Venkataraman, 2000), which is embodied in entrepreneurship (Baron 2004a; Hisrich, Peters \& Shepherd, 2005). As academic researchers or new ventures often lack credibility with a range of stakeholders such as investors, suppliers, customers, and potential employees (Smilor, 1987), UBIs have a role in providing these new ventures with the legitimacy and "the value-added services to facilitate the cyclical progression of opportunity targeting and making strategic decisions regarding the allocation of scarce resources in pursuit of value adding opportunities” (Kodithuwakku \& Rosa, 2002, pp. 403). For this study, a clear connection is established between the three stages of the incubation process; pre-main-post incubation process and the entrepreneurial life cycle. Pre-incubation relates to the activities needed to support the potential entrepreneur in developing his or her business idea, while the 
main incubation stage refers to the integrated mix of services and operational support provided to the incubatees selected for their growth potential, and finally, the post incubation stage refers to the activities to support the expansion stage.

Following Hackett and Dilts (2004a) real options-driven theory, an incubator takes on a role like an "ideal type" venture capitalist during the selection performance in choosing potential incubatees from a pool of candidates; followed by monitoring and provision of business assistance in observing and assisting incubatees; as well as resource munificence in terms of assets, capabilities, organisational processes, attributes, information, and knowledge to facilitate the entrepreneurial process. These resources which include both tangible and intangible resources such as capabilities and assets are made available to incubatees to help them to respond to market opportunities or threats (Christensen \& Overdorf, 2000). UBIs act as an accelerator for the commercialisation of the universities' research outcome (Hassan, 2020). There is a limited number of studies that applied Hackett and Dilts (2004a) through the lens of real options-driven theory, except for Posza (2019) who identified the real options at every stage of the business incubation process in the eight Hungarian business incubators. As explained, UBIs' activities are comparable to investing in companies and as such the real options-driven theory answer which factors should be taken into account when selecting the incubatees, and whether predefined criteria contribute to the economic results of incubation, i.e., the entrepreneurial success (Moreira \& Carvalho, 2012).

In other words, the university incubator's role and performance in the entrepreneurial process depends on the ability of the incubator (or the incubator manager) to identify and create real options that can be found in each stage of the incubation process (pre-incubation, incubation, post incubation). Incubators control and link resources with the objective of facilitating the successful new venture development of the incubatees while simultaneously containing the cost of their potential failure (Hackett \& Dilts, 2004a). This implies that beyond the low-cost physical facilities offered by UBIs, it is crucial to recognise the importance of the entire incubators' networks (such as funders, government agencies and industry partners) and the roles they play in incubating new ventures to success; hence facilitating the entrepreneurial process. At the same time, it is crucially important for UBI to consider the type of resources provided by the incubator and how they should be integrated to provide a sustainable competitive advantage (Schütte, 2019), and not take the view that they simply exist (Stinchcombe, 2000) at the incubatees' disposal. In short, UBI must adopt an entrepreneurial process approach to constantly adjust its resource mix to maintain the survivability and growth 
of the spins-offs, which otherwise might not survive the valley of death. This is in line with the resource-based view (RBV) theory that provides a way for the incubator management researcher to understand, in particular, the role of the intangible resources such as network and managerial capabilities of the incubator managers in the success of the spin-offs. Both Patton, Warren and Bream (2009) and Schütte (2019) pointed out that the provision of resources by an incubator should match with the needs of its incubatees during their entrepreneurial life cycle.

Most of the papers reviewed on the topic of incubation does not portray the incubator as an active tool to stimulate the entrepreneurial process from the inception of an idea to commercialisation and launching of a viable business (Hackett \& Ditts, 2004a, Aernoudt, 2005). Thus, this qualitative study undertakes to integrate the ROT and RBV theories to understand how UBIs can play their role more effectively in transforming business ideas into business opportunities, undertake new entrepreneurial actions, and innovate constantly (Gay \& Dousset, 2005; Tsai, 2009).

\section{Methodology}

Research design

This research study aims to investigate how UBIs contribute to the entrepreneurial process of the incubatees. A multiple case studies methodology was adopted for this study. It is a methodology that has been extensively applied in qualitative research (Yazan, 2015), by gathering empirical material over a period of time to conduct a detailed investigation on an entire organisation (Zikmund, 1997). In-depth, semi-structured, face-to-face interviews were conducted over six months. Although this methodology had some limitations in its generalisability and time (Rahman, 2017); it had been used by Abdul Khalid et al. (2014), Sukhur and Abu Bakar (2018), Ismail and Sidek (2019) in their research on Malaysian business incubators. This study was solely based on the perspective of the incubator, or incubator-level analysis, which had been adopted by Verma (2004), Al-Mubaraki and Busler (2013), AlMubaraki and Busler (2015), Oliveira and Vieira (2016), Gozali et al. (2016), and Sukhur and Abu Bakar (2018).

\section{Sample population}

At the time of this study, five research universities, Universiti Putra Malaysia (UPM), Universiti Malaya (UM), Universiti Kebangsaan Malaysia (UKM), Universiti Sains Malaysia 
(USM) and Universiti Teknologi Malaysia (UTM) were chosen because UPM, UM and UTM have an established incubator; while UKM and USM have a Transfer Technology Office (TTO). For this study, TTO is regarded as part of the incubator-incubation process, and that incubators are linked to the technology transfer strategy of the TTO. On top of these five, there are about two dozen UBIs in Malaysia, and very little is known about them. The participants chosen for this study were the incubator managers and staff that were involved in the day-today operations in managing the incubation process in the five Malaysian research universities. They were selected using the purposive sampling method based on the researcher's judgement due to the limited number of people that could serve as primary data sources in the management of the incubators (Dudovskiy, n.d.). A total of 13 participants were selected from UPM Putra Science Park (PSP) InnoHub, UM Centre of Innovation \& Commercialisation (UMCIC) UMXcelerate, UKM Centre for Collaborative Innovation (PIK), USM Centre for Innovation and Consultation (CIC), and UTM Innovation and Commercialisation Centre (ICC). Phone calls and emails were used as the medium of communication to contact the potential respondents for permission to conduct the interviews. All had agreed to participate in the interview sessions voluntarily. They were duly informed of the study's objective and potential benefits, as well as given the assurance of their confidentiality in participation.

\section{Research instrument}

A series of interviews was conducted with the incubator managers and staff to collect first-hand information on the roles of UBIs in promoting entrepreneurial activities among students, researchers, and entrepreneurs (incubatees), from the perspective of the incubator managers and staff. A semi-structured interview guide which comprised open-ended questions was used to understand the experience of the participants and their involvement in the incubation process (refer to appendix). It was developed based on key themes such as academic incubator's structure, purpose, and incubation process.

\section{Data collection procedures}

In-depth, semi-structured, face-to-face interviews were carried out with the 13 respondents. In-depth interviews provided a comfortable atmosphere for interviewees to engage in conversations and express their views freely. They also allowed the researcher to collect rich information by asking follow-up questions, probing deeper to obtain additional information, as well as confirming on previous answers (Queirós, Faria \& Almeida, 2017). Each interview 
lasted approximately 75 to 150 minutes. It was conducted by the principal investigator, and supported by the co-researcher. Four of the interviews were conducted at the incubator office in the respective university, while another two interviews were carried out via Skype virtual calls due to the time and access limitation. All of the interviews were conducted separately at a different time, but the set of interview questions remained the same. The interview sessions began by describing the purpose of the study to the participants to build rapport with them, followed by asking open-ended questions to more specific questions. Prompts were also used to facilitate the sessions.

Sources from secondary data were adopted by reviewing past literature from journal articles, government reports, and consulting reports to identify the roles for comparison across the five UBIs and also to enrich the findings for this study.

\section{Data analysis procedures}

All interview sessions were recorded and transcribed verbatim. The transcriptions were then thematically analysed and coded using qualitative analysis of a priori approach, based on the researcher's understanding of the UBI's roles in the entrepreneurial process. After that, the researcher conducted cross-case analysis, where data from the five UBIs were combined together to give an overview, make comparisons, and draw conclusions. Empirical data from multiple sources were also used to corroborate the research findings. This allows triangulation of data, which increased the rigor, breadth, complexity, richness, and depth of the findings (Rashid et al., 2019).

This study adopted the four criteria proposed by Guba (1981) to ensure trustworthiness. To establish credibility, the findings of this study were cross-checked with past studies, and the process of data collection, data analysis, and results of this study were examined by a qualitative professor to ensure reliability. Since most of the context of UBIs is largely similar across universities, transferability was established. Finally, to ensure confirmability, an auditable trail detailing the process of data collection, analysis, and interpretation was established. 


\section{Presentation of findings and discussion}

Roles of the incubators in the five Malaysian research-led universities

The analysis of the data was coded and eight themes emerged, namely (1) incubator management, (2) monitoring of incubatees, (3) business assistance services, (4) professional management services, (5) networking, (6) accessibility to capital/funds, (7) selection process, and (8) exit criteria. These themes were further categorised into four roles of the incubator system in Malaysia, namely (1) selection process, (2) monitoring of incubatees, (3) provision of infrastructure, shared facilities, and business support services, and (4) access to networks and financing.

The following section discusses the main elements of the roles of incubators in the incubation process in relation to how UBIs in research universities play their role in bringing tangible contribution to the entrepreneurial process.

\section{Selection process}

As mentioned, UBIs are viewed as the entrepreneurial hubs of the universities and the performance of the incubators hinges on the performance of the incubatees. Thus, the selection process is indisputably a critical component for successful incubation and the number of graduated companies will be directly proportional to the quality of the selection process (Bizzotto, 2003). Having a well-executed selection would ensure that only high quality incubatees are admitted to the incubation process. It is clear that the screening or the selection process is important to ensure a suitable fit or a match between the mission and resources of the incubation programme and the incubatees' needs (Walker, 2004, Amezcua et al., 2013). Three broad categories around management, finances, and market were some of the selection matrix used (Abdul Khalid, Kayani, \& Gilbert, 2018). However, according to Wulung et al. (2014), despite the importance of the selection process, there have been little or no effort to date to formulate a model that addresses multi-criterion incubatee selection.

Our findings showed that different UBIs used a different selection process and criteria. Most used a single criterion except for InnoHub. InnoHub chooses the applicants that have deep technology-based invention and the availability of an 'external CEO' to team up with the researcher/incubatee; while the other four incubators give more emphasis on product characteristics. To be eligible to participate in the incubation programme, an application for a patent must have been filed or they have developed a pre-production prototype of the product. 
Whilst such criteria are useful, UBIs may also want to consider a cultural fit (Lewis et al., 2011) and the characteristics of the academic entrepreneur (Miller et al., 2018), which is not highlighted as one of the criteria for assessment. According to Colbert et al. (2010), business incubation programme's client selection should include coachability, viability, industry sector, stage of development, and growth potential. Various studies on the incubation process concur that the selection performance is an important part of the incubation process (Hackett and Ditts, 2004a; Bergek \& Norman, 2008), and screening for future incubatees should not just focus narrowly on one criterion or two criteria. This is line with the structural contingency theory (Ketchen, Thomas \& Snow, 1993) which suggests that the configuration of the incubator must obtain "fit" with the environmental and incubatee's needs and characteristics in order to achieve incubation success. Using multiple selection criteria can compensate the weakness of one criterion with another. For instance, the weakness of a business plan can be compensated by the characteristics of the academic entrepreneur.

\section{Monitoring of incubatees}

According to the interview data, only UPM InnoHub, UKM PIK, and UTM ICC revealed that they monitor their incubatees' progress during the incubation programme. Linder (2003), O’Neal (2005), Patton, Warren, and Bream (2009) highlighted the importance of monitoring leading to a smooth incubation process. However, they cautioned that overly formal monitoring and evaluation system can hinder entrepreneurial activities. Proactive and real-time feedback can help to prevent costly and potentially terminal business mistakes (Hackett \& Dilts, 2004a; Abetti, 2004).

According to the interview data, most of the incubator systems have clear milestone KPIs for their respective incubatees for its structured incubation programme such as completion of required training, application for fund applications per year, completion of market validation activities, and achievement in sustainable business plans before incubatees can graduate from the programme. At the university level, the Malaysia Research Assessment (MyRA) indicators which is tailored to foster the excellence of research outputs are used. Such indicators include the number of publications, IPs filed, number of commercialisations, number of licensing knowhow, and number of new companies that commercialised university's innovations in the year of assessment. Most of the participants informed that there is also frequent engagement with their incubatees to enhance the quality of the monitoring system. 
However, most do not have clear graduation criteria, and incubatees are allowed to continue to stay in the incubator until they become sustainable. In InnoHub and UMXcelerate, the start-ups are also not encouraged to leave the incubator even though they can hold the equity. Schwartz (2009) cautioned the tendency of start-ups becoming overdependent on the incubator's support by outstaying their tenancy in the incubation programme.

\section{Provision of infrastructure, shared facilities, and business support services}

With regards to the provision of office infrastructure and support services, UPM InnoHub, UM UMXcelerate, and UTM ICC provide physical office space, and shared office facilities like desks, mail, wifi, photocopy machine, lab services to its incubatees; whereas UKM PIK and USM CIC only emphasise on offering professional management services especially in business collaboration/matching, that is helping incubatees to license their products/technologies to an external partner/company in the industry. Notably, InnoHub, UMXcelerate, and ICC focus on giving both tangible and intangible services; whereas PIK and CIC emphasise solely on the intangible services, thus functioning like a virtual incubator where the focus is on facilitating the entrepreneurial process through supporting the provision of networks, financial resources, and training.

Based on the interview data, all five incubators are set up to facilitate their incubatees from IP to commercialisation and technology licensing. Notably, InnoHub has moved beyond the provision of business support services and inching towards a $4^{\text {th }}$ generation incubator type of support. It provides training by international organisations, market research, partner and sales development, marketing of research products in exhibitions (for example, ITEX, IGEM), press releases, and garden parties for investors. Earlier generations of incubation were found to improve start-up performance only marginally (Schwartz, 2013), and the network-based generation incubation or $4^{\text {th }}$ generation incubators are expected to be superior in helping incubatees to succeed (Theodorakopoulos et al., 2014). As at 2018, InnoHub by UPM has successfully produced more than fifty technopreneurs with products that have market values since its inception in 2013. Whether it is $2^{\text {nd }}$ or $3^{\text {rd }}$ generation incubator should not be the main concern, universities should look at how to increase the number of spins-offs from the incubators. An incubator without a well-established value ecosystem and network is worthless to the entrepreneurial process. 


\section{Access to networks and financing}

According to Wiggins and Gibson (2003), Lee and Osteryoung (2004), Pena (2004), and Soetanto (2004), incubators with affiliations to universities, government, non-profit and private organisations are able to provide entrepreneur and community support to their incubatees. All five incubator systems in our sample are tied to their universities, and have holding companies, entrusted to accelerate the commercialisation of $\mathrm{R} \& \mathrm{D}$ and Intellectual Properties, and they also serve as Holding Company for the spinoffs companies; although with varying degrees of involvement. Our research findings have demonstrated that the five research universities emphasise on interorganisational relationships, that is relationships with universities, private and public institutions, which is in line with the proposition from Sousa et al. (2018). InnoHub, UMXcelerate, and PIK have linkages with institutions such as but not limited to MaGIC, ITMA, MyIPO, MDEC, etc. that will enhance knowledge sharing (Shukur \& Abu Bakar, 2018), problem-solving skills, and drive a start-up's success (Verma, 2004). Nevertheless, incubators should also encourage linkages between its own incubatees and graduated start-ups, as well as among incubatees themselves so as to foster exchange of feedbacks, experiences, and ideas between them (Aernoudt, 2004; Lee \& Osteryoung, 2004; Gerlach \& Brem, 2015).

In terms of accessibility to funding, all five UBIs in this study have some form of funding arrangements in place to assist their incubatees at different stages of business development. InnoHub provides linkages to venture capitalists, public funding organisations, and angel investors; UMXcelerate has linkages with venture capitalist; PIK has its own inhouse funders (Innovation Fund, Lab-2-Market, CREST) and incubation funds up to RM100,000; CIC has its own prototype grant worth RM25,000 to RM50,000, and linkages to venture capitalist; ICC provides its own PRGS grant for prototype at RM20,000, precommercialisation loan worth RM50,000 to RM100,000, as well as connections to venture capitalist, and public funding organisations. In this case, InnoHub, PIK, and ICC appear to have more funding arrangements to support their incubatees in their early phase of entrepreneurial development.

\section{Incubator managers' competencies}

The selection process, monitoring, provision of infrastructure, shared facilities and business support services, as well as access to networks and financing will not be possible without a competent incubator manager that orchestrates the entire incubation process to drive 
the entrepreneurial activities. Therefore, it is important to ensure that the selection process for the management and staff of the UBIs is done well to improve the "fit". All prospective staff members of the incubators must have the necessary level of motivation and passion to take an active role in the incubator-incubation process and also allow for better calibration of the incubation programmes with the realities of the community. The operational aim of UBIs is to create the best possible conditions for incubatees to eventually run their own businesses. UPM InnoHub, UM UMXcelerate, and UKM PIK have incubator managers with business acumen and deep external networks to manage the incubators. According to Redondo and Camarero (2017), an incubator manager with industry experience and has deep business networks will have a higher tendency to drive the incubator's success.

All five research universities have a team that supports and handles the daily operations in the incubators, such as IP management, technology licensing, promotion, and training; although it was found that many of the staff are hired on a temporary contract basis. Ismail and Sidek (2019) suggested incubators to hire skilled permanent staff. This is important to ensure that the right people with the right passion, motivation, and entrepreneurial mindset is hired to drive the entrepreneurial activities in the universities. The sustainability of the incubator within the university will be questioned if the incubators are staffed with people who are constantly on a look out for their next job or worry about whether their employment contract will be renewed instead of focusing on creating value to enhance the entrepreneurial process. Further, the need to strengthen the competency profile of the incubator manager should be reinforced as it has a direct bearing on the readiness of the future "entrepreneurs" participating in the incubation process.

Table 1 summarises and presents the roles of the five UBIs in Malaysia based on the research findings of this study. 


\section{Table 1}

Summary of the UBIs' Roles

\begin{tabular}{|c|c|c|c|c|c|}
\hline UBIs & InnoHub & UMXcelerate & PIK & CIC & ICC \\
\hline $\begin{array}{l}\text { Selection } \\
\text { Process }\end{array}$ & $\begin{array}{l}\text { Market/Team - } \\
\text { Deep tech start- } \\
\text { ups }\end{array}$ & $\begin{array}{l}\text { Product- } \\
\text { IP/Prototype }\end{array}$ & Product- IP & $\begin{array}{l}\text { Product - } \\
\text { Prototype }\end{array}$ & $\begin{array}{l}\text { Product- } \\
\text { IP/Prototype }\end{array}$ \\
\hline Monitoring & $\begin{array}{l}\text { Monitoring } \\
\text { based on } \\
\text { milestones }\end{array}$ & N/A & Monitoring & N/A & Monitoring \\
\hline $\begin{array}{l}\text { Infrastructure, } \\
\text { Facilities \& } \\
\text { Services }\end{array}$ & $\begin{array}{ll} & \text { Tangible \& } \\
\text { intangible } \\
\text { - } \\
\text { Moving } \\
\text { towards } 4^{\text {th }} \\
\text { generation } \\
\text { support }\end{array}$ & $\begin{array}{ll}\text { - } & \text { Tangible \& } \\
& \text { intangible }\end{array}$ & - Intangible & - Intangible & $\begin{array}{l}\text { Tangible \& } \\
\text { intangible }\end{array}$ \\
\hline $\begin{array}{l}\text { Access to } \\
\text { Networks \& } \\
\text { Financing }\end{array}$ & $\begin{array}{l}\text { - Tied to } \\
\text { university \& } \\
\text { have holding } \\
\text { company } \\
\text { - Emphasis on } \\
\text { interorganisatio } \\
\text { nal } \\
\text { relationships } \\
\text { - Funding } \\
\text { arrangements } \\
\text { in the early } \\
\text { stage }\end{array}$ & \begin{tabular}{|l} 
Tied to \\
university \& \\
have holding \\
company \\
Emphasis on \\
interorganisat \\
ional \\
relationships \\
Funding \\
arrangements \\
in the early \\
stage
\end{tabular} & 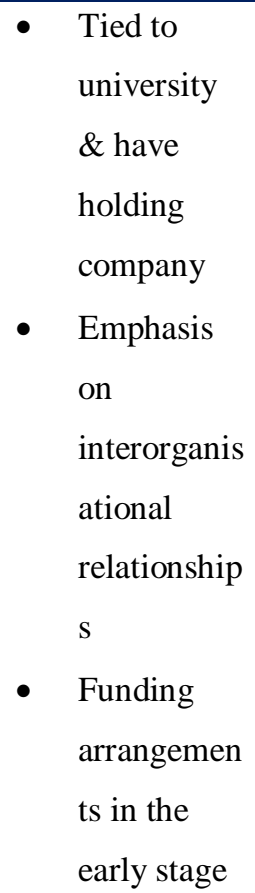 & 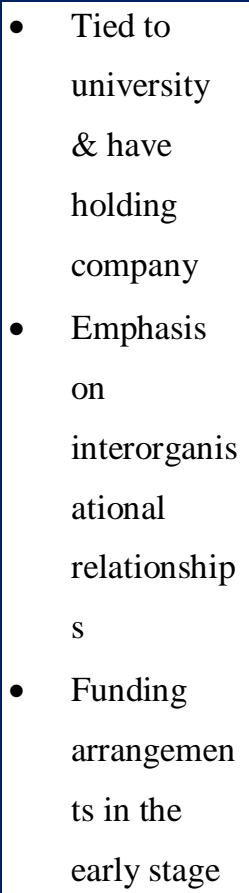 & 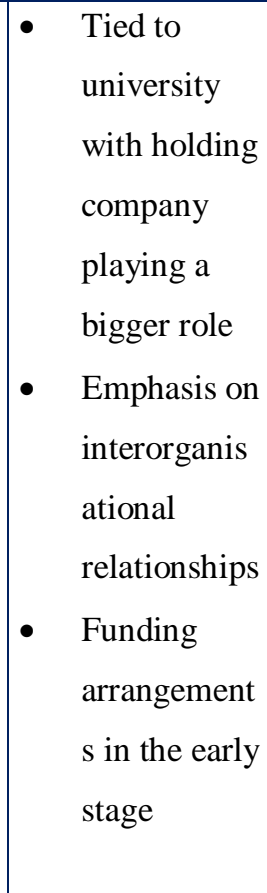 \\
\hline
\end{tabular}

Source: Authors.

Framework of UBI's roles in driving the entrepreneurial process

Figure 2 depicts the conceptual framework to illustrate the UBI's roles in the entrepreneurial process. It illustrates the roles that the UBI plays at different stages of the incubation process to foster entrepreneurial intention and activities, and the outcome in each 
phase. For this paper, the incubation process is divided into three stages according to Abreu, Swirski and Goncalo (2006). At the pre-incubation stage, the idea for new product/service or opportunity is germinated, and the UBIs play the important role in fostering the business idea validation of university researchers. This is supported by Stuart and Sorenson (2003b)'s study that found that business incubation activities have positive implications for validating business ideas generated by budding entrepreneurs. UBIs select incubatees based on their evaluation of the market, product, and team potential, and alignment to the UBI of university's vision and focus. This helps to determine the researcher's intention and decision to proceed or not. It is clear that UBI has the strategic objective to prepare the next generation of entrepreneurs by exploiting the research outcome as a business opportunity. In the main incubation stage, UBI supports the establishment and growth of new businesses with tangible (low-cost space rental, shared services, business support, funding in the form of grants) and intangible resources (knowledge, network access to market, source of financing, mentoring and monitoring). It serves as a cost-effective tool to catalyse the entrepreneurial resource mobilisation and accelerate the commercialisation of the research outcomes of the universities. In short, it serves as a window into an early-stage venture development (Clough et al., 2019) by providing physical infrastructure, managerial support, access to funding mechanisms and business partnerships to help nascent entrepreneurs to adapt to the market and succeed after graduating. In the post incubation stage, the new venture leaves the UBI and operates in the market on its own. According to Lasrado et al. (2016), university affiliation is an important contingency that affects the relationship between firms' participation in incubators and their subsequent performance. However, there is very little knowledge about the development and management of the post incubated firms (De Paula et al., 2015) as these post incubated firms no longer enjoy the benefits of access to a rich portfolio of resources and facilities. Hence, it is important that more attention should be placed on the development of post incubation firms, as entrepreneurial process of venture creation is a cyclical progression of opportunity targeting and making strategic decisions regarding the allocation of scarce resources in pursuit of value-adding opportunities (Kodithuwakku \& Rosa, 2002). 
Figure 2

Conceptual framework of UBI's roles in driving the entrepreneurial process

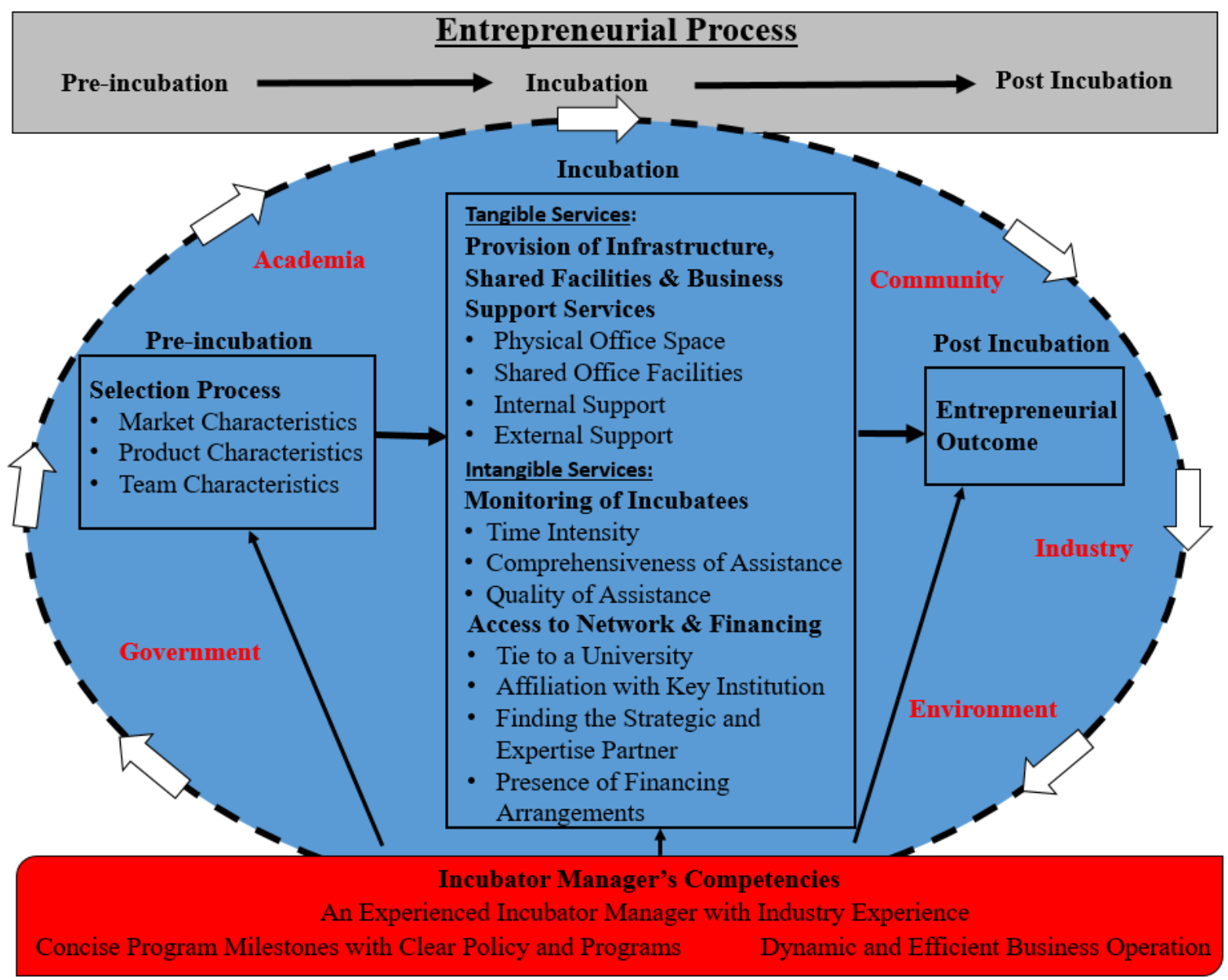

Source: Authors.

\section{Conclusion and recommendation}

In conclusion, this paper has provided a window to the "black box" of the incubation process in the UBIs. The developed conceptual model as depicted in the Figure 2 above provides an understanding of the practical aspects of the UBIs' activities, and how they are mobilised to support the entrepreneurial process through recognising an opportunity to developing the business plan; determining the resources required; and managing the resulting enterprise (Hisrich \& Peters, 2002). Hence, the role and effectiveness of the incubators in the entrepreneurial process will depend on the quality of the incubatee's screening in the preincubation process. A multi-criterion incubatee selection beyond the market, team, and product potential is essential to increase the success rate of the incubated firms as UBI is part of a university, and hence must take into account the fit and long-term strategic goals of the 
university to be better able to leverage on the university's rich resources. In the main incubation period, the mobilisation and provision of resources is the key to providing the incubated firm with the appropriate resources. Intangible specialised services are found to be much more needed compared to the tangible services (Akcomak, 2009). In other words, the services or resources provided by the incubator need to be optimally mixed between tangible and intangible, and carefully monitored for their efficacy in line with the resource-based view. For example, instead of focusing on an interorganisational relationship, UBIs are advised to facilitate interactions between its incubatees and graduated start-ups, and also between the incubatees themselves to exchange information, experience, and knowledge, and facilitate access to external sources of funding beyond the university grants to promote the entrepreneurial process. Lastly, the entrepreneurial process is not only the series of activities that leads to a new firm creation but also includes an entrepreneurial exit (DeTienne, 2010). At the post incubation stage, the firm is expected to be able to operate in the market on its own. At this stage, the incubator's services are no longer available to these incubated firms. Graduation from an incubator can cause an instant negative effect on survival in the post incubation period. In a follow-up study, Schwartz (2013) concluded that the findings do not support the presumption of sustainable and strong firm growth after incubation. His study also revealed that $20 \%$ of the new ventures will fail within the first three years as a result of the termination of support services, and the failure rate will reduce with time the moment they graduate from the incubator. Access to highly qualified human resources and funding arrangements during the growth phase is also a crucial post incubation success. Hence, it is important that aftercare services in terms of the continuation of support services in the post incubation phase are provided as the new ventures are very vulnerable when they first leave the incubation environment.

As discussed above, UBI manager acts as a linchpin to coordinate and control the flow of resources to the incubatees to drive the incubation success by shepherding universities' inventions/innovations through the technology transfer process, across all the various stakeholders. Hence, an incubator manager's competencies provided by experienced incubator managers with commercial acumen is also an important construct to persuade external stakeholders of the legitimacy of their incubatees. By generating legitimacy with external stakeholders, the problems that start-ups face can be dramatically reduced (Delmar \& Shane, 2004), and their liability of newness overcome (Ferguson \& Olofsson, 2004). As we have 
explained, most if not all the selected incubatees have limited business experience as they are mostly academic researchers.

In conclusion, the framework above contributes to the understanding of the role of UBIs in creating value through the multi-theoretical lens of real options-driven theory (ROT) and resource-based view (RBV). An incubator that is well-funded, has access to vast industrial networks and a capable management team will have a higher likelihood to drive the success of its incubatees (Hackett \& Dilts, 2004a). By integrating the real options-driven theory and the resource-based view theory, the paper contributes towards the understanding of the role of UBI in identifying the right potential entrepreneur, mobilising and optimising the right balance of tangible and intangible resources, and monitoring of the incubatees in driving the entrepreneurial process. It also highlights the lack of evidence and emphasis of the post incubation period support. Lastly, it serves as a reminder that UBIs need to be innovative themselves to achieve the university's "Third Mission" to foster entrepreneurship for economic and social development, and be regarded as an effective tool to promote academic entrepreneurship, and have a decisive role in the entrepreneurial process.

\section{Acknowledgement}

We thank all the five research universities for their valuable contribution to this paper.

\section{Funding}

This project is supported by the Malaysian Ministry of Higher Education Fundamental Research Grant Scheme (FRGS): FRGS/1/2018/SS03/HELP/02/1.

\section{References}

Abdul Khalid, F. A. (2012). An empirical analysis into the underlying components impacting upon business incubation process in Malaysia ICT incubators. [PhD dissertation, RMIT University]. RMIT University. Retrieved from https://researchrepository.rmit.edu.au/esploro/outputs/doctoral/An-empirical-analysisinto-the-underlying-components-impacting-upon-business-incubation-performance-ofMalaysian-ICT-incubators/9921861116701341

Abdul Khalid, F., Gilbert, D., \& Huq, A. (2014). The way forward for business incubation process in ICT incubators in Malaysia. International Journal of Business and Society, 15(3), 395-412. Retrieved from http://www.ijbs.unimas.my/repository/pdf/Vol15-no3paper2.pdf 
Abdul Khalid, F., Kayani, A. A., \& Gilbert, D. (2018). The impact of monitoring and business assistance intensity on Malaysian ICT incubatees' performance. Article presented at the MATEC Web of Conferences MUCET 2017, Malaysia. Retrieved from https://research.monash.edu/en/publications/the-impact-of-monitoring-and-businessassistance-intensity-on-mal

Abetti, P. A. (2004). Government-supported incubators in the Helsinki Region, Finland: Infrastructure, results, and best practices. Journal of Technology Transfer, 29(1), 1940. https://doi.org/10.1023/B:JOTT.0000011179.47666.55

Abreu, F., Swirski, Y., \& Gonçalo, C. (2006). Aprendizagem e criação do conhecimento em incubadoras. In Anais do XXX Encontro Nacional da Associação Nacional de Pósgraduação e Pesquisa em Administração (EnANPAD). Salvador: ANPAD.

Adkins, D. (1996). A decade of success: NBIA 10th anniversary survey of business incubators, 1985-1995. National Business Incubation Association, Athens: OH. Retrieved from National Business Incubation Association 10th anniversary survey of business incubators, 1985-1995: A decade of success: Adkins, Dinah: Amazon.com: Books

Aernoudt, R. (2004). Incubators: Tool for entrepreneurship. Small Business Economics, 23, 127-135. https://doi.org/10.1023/B:SBEJ.0000027665.54173.23

Aernoudt, R. (2005). Business angels: The smartest money for starters? Plea for a renewed policy focus on business angels. International Journal of Business, 10(3), 271-284.

Retrieved from

https://www.researchgate.net/publication/228165930_Business_Angels_The_Smartest _Money_for_Starters_Plea_for_a_Renewed_Policy_Focus_on_Business_Angels

Akcomak, S. I. (2009). Incubators as tool for entrepreneurship promotion in developing countries. MERIT Working papers 2009-054. United Nations University-Maastricht Economic and Social Research Institute on Innovation and Technology (MERIT). http://www.merit.unu.edu/publications/wppdf/2009/wp2009-054.pdf

Al-Mubaraki, H. M., \& Busler, M. (2013). The effect of business incubation in developing countries, European Journal of Business and Innovation Research, 1(1), 19-25. Retrieved from https://www.eajournals.org/wp-content/uploads/The-Effect-ofBusiness-Incubation-in-Developing-Countries.pdf

Al-Mubaraki, H. M., \& Busler, M. (2015). The importance of business incubation in developing countries: Case study approach. International Journal of Foresight and Innovation Policy, 10(1), 17-28. https://doi.org/10.1504/IJFIP.2015.070054

Amezcua, A., Grimes, M., Bradley, S. W., \& Wiklund, J. (2013). Organizational sponsorship and founding environments: A contingency view on the survival of business incubated firms, 1994-2007. The Academy of Management Journal, 56(6), 1628-1654. https://doi.org/10.5465/amj.2011.0652 
Baron, R. A. (2004a). The cognitive perspective: A valuable tool for answering entrepreneurship's basic “why” questions. Journal of Business Venturing, 19(2), 221239. https://doi.org/10.1016/S0883-9026(03)00008-9

Bergek, A., \& Norrman, C. (2008). Incubator best practice: A framework. Technovation, 28(1-2), 20-28. http://dx.doi.org/10.1016/j.technovation.2007.07.008

Bizzotto, C. E. N. (2003). The incubation process. Brazil: Gene Institute - Fundação Universidade Regional de Blumenau Santa Catarina. Retrieved from https://www.scribd.com/document/123212360/The-Incubation-Process-September2003

Campbell, C. (1989). Change agents in the new economy: Business incubators and economic development. Economic Development Review, 7(2), 56-59. Retrieved from https://www.semanticscholar.org/paper/Change-Agents-in-the-new-economy\%3ABusiness-and-Campbell/d9af67433cbeabb624ee5a318ef47617f7ea067a

Christensen, C. \& Overdorf, M. (2000). Meeting the challenge of disruptive change. Harvard Business Review. http://innovbfa.viabloga.com/files/HBR__Christensen__meeting_the_challenge_of_ disruptive_change__2009.pdf

Clough, D. R., Tommy, P. F., Vissa, B., \& Wu, A. (2019). Turning lead into gold: How do entrepreneurs mobilize resources to exploit opportunities. The Academy of Management Annals, 13(1), 240-271. https://doi.org/10.5465/annals.2016.0132

Colbert, C., Adkins, D., Wolfe, C., \& Lapan, K. (2010). Best practices in action: Guidelines for implementing first-class business incubation programs [Revised 2nd ed.]. Athens, $\mathrm{OH}$ : National Business Incubation Association.

De Paula, H.C., Starling, D.B., Nascimento, J.F. and Barbosa, F.V. (2015). Mensuração da inovação em empresas de base tecnologica, Review of Administration and Innovation Rai, 12(4), 232-253. Retrieved from https://www.revistas.usp.br/rai/article/view/102277

Delmar, F., \& Shane, S. (2004). Legitimating first: Organizing activities and the survival of new ventures. Journal of Business Venturing, 19(3), 385-410. https://doi.org/10.1016/S0883-9026(03)00037-5

DeTienne, D. R. (2010). Entrepreneurial exit as a critical component of the entrepreneurial process: Theoretical development. Journal of Business Venturing, 25, 203-215. https://doi.org/10.1016/j.jbusvent.2008.05.004

Dudovskiy, J. (n.d.). Purposive sampling. Business Research Methodology. https://researchmethodology.net/sampling-in-primary-data-collection/purposive-sampling

Dutta, S., Lanvin, B., \& Wunsch-Vincent, S. (2018). Global Innovation Index 2018: Energizing the World with Innovation. https://www.wipo.int/edocs/pubdocs/en/wipo_pub_gii_2018.pdf 
Etzkowitz, H. (2003). Research groups as 'quasi-firms': The invention of the entrepreneurial university. Research Policy, 32(1), 109-121. https://doi.org/10.1016/S00487333(02)00009-4

Ferguson, R., \& Olofsson, C. (2004). Science parks and the development of NTBFs-location, survival and growth. The Journal of Technology Transfer, 29(1), 5-17. https://doi.org/10.1023/B:JOTT.0000011178.44095.cd

Franco, M., Haase, H., \& Correia, S. (2015). Exploring factors in the success of creative incubators: A cultural entrepreneurship perspective. Journal of the Knowledge Economy, 6(1), 467-640. https://doi.org/10.1007/s13132-015-0338-4

Gay, B. \& Dousset, B. (2005). Innovation and network structural dynamics: Study of the alliance network of a major sector of the biotechnology industry. Research Policy, 34(10), 1457-1475. https://doi.org/10.1016/j.respol.2005.07.001

Gerlach, S., \& Brem, A. (2015). What determines a successful business incubator? Introduction to an incubator guide. International Journal of Entrepreneurial Venturing, 7(3), 286-307. https://doi.org/10.1504/IJEV.2015.071486

Gordon, I., Hamilton, E., and Jack, S. (2012). A study of a university-led entrepreneurship education programme for small business owner/managers. Entrepreneurship \& Regional Development, 24(9-10), 767-805. https://doi.org/10.1080/08985626.2011.566377

Gozali, L., Masrom, M., Zagloel, T. Y. M., \& Norehan Haron, H. (2016). A framework of successful business incubators for Indonesian public universities, International Journal of Technology, 6, 1086-1096. https://doi.org/10.14716/ijtech.v7i6.3351

Guba, E. G. (1981). Criteria for assessing the trustworthiness of naturalistic inquiries. Educational Communication and Technology Journal, 29, 75-91. Retrieved from https://www.jstor.org/stable/30219811

Hackett, S. M. \& Dilts, D. M. (2004a). A real options-driven theory of business incubation. Journal of Technology Transfer, 29, 41-54. https://doi.org/10.1023/B:JOTT.0000011180.19370.36

Hassan, N. (2020). University business incubators as a tool for accelerating entrepreneurship: theoretical perspective. Review of Economics and Political Science, 2631-3561. https://doi.org/10.1108/REPS-10-2019-0142

Hisrich, R. D. \& Peters, M. (2002). Entrepreneurship [5 $5^{\text {th }}$ edition]. McGraw-Hill Companies Inc. Retrieved from https://www.textbooks.com/Entrepreneurship-5thEdition/9780072536201/Robert-D-Hisrich-and-Michael-P-Peters.php

Hisrich, R. D., Peters, M. P., \& Shepherd, D. A. (2005). Entrepreneurship [6th edition]. New York: McGraw-Hill/Irwin. Retrieved from https://www.textbooks.com/Entrepreneurship-6th-Edition/9780072971859/Robert-DHisrich-Michael-P-Peters-and-Dean-AShepherd.php?CSID=2QZADOSDBMZOTC2TKKO2KMSCB \&CSID=2QZADO2A QQKZDUMMTO2UAMSOB 
Ismail, N. \& Sidek, S. (2019). Determinant factors for commercialising research products in Malaysian public universities. International Journal of Innovative Technology and Exploring Engineering (IJITEE), 8(6S4), 780-787. https://doi.org/10.35940/ijitee.F1157.0486S419

Johnstone, A., \& Huggins, R. (2016). Drivers of university-industry links: The case of knowledge-intensive business service firms in rural locations. Regional Studies, 50(8), 1330-1345. https://doi.org/10.1080/00343404.2015.1009028

Ketchen, D. J. J., Thomas, J. B., \& Snow, C. C. (1993). Organizational configurations and performance: a comparison of theoretical approaches. Academy of Management Journal, 36(6), 1278-1313. https://doi.org/10.5465/256812

Kodithuwakku, S. S. \& Rosa, P. (2002). The entrepreneurial process and economic success in a constrained environment. Journal of Business Venturing, 17(5), 431-465. https://doi.org/10.1016/S0883-9026(01)00074-X

Lalkaka, R. (2002). Technology business incubators to help build an innovation-based economy. Journal of Change Management, 3(2), 167-176. https://doi.org/10.1080/714042533

Larty, J., Jack, S., \& Lockett, N. (2016). Building regions: A resource-based view of a policyled knowledge exchange network. Regional Studies, 51(7), 994-1007. https://doi.org/10.1080/00343404.2016.1143093

Lasrado, V., Sivo, S., Ford, C., O’Neal, T., \& Garibay, I. (2016). Do graduated university incubator firms benefit from their relationship with university incubators? The Journal of Technology Transfer, 41, 205-219. https://doi.org/10.1007/s10961-015-9412-0

Lee, S. S., \& Osteryoung, J. S. (2004). A comparison of critical success factors for effective operations of university business incubators in the United States and Korea. Journal of Small Business Management, 42(4), 418-426. https://doi.org/10.1111/j.1540627X.2004.00120.x

Lewis, D. A., Harper-Anderson, E., \& Molnar, L. A. (2011). Incubating success: Incubation best practices that lead to successful new ventures. University of Michigan. http://edaincubatortool.org/pdf/Master\%20Report_FINALDownloadPDF.pdf

Linder, S. (2003). State of the business incubation industry. NBIA Publications.

Mahmood, N., Jamil, F., \& Yasir, N. (2017). Role of business incubators in entrepreneurship development in Pakistan. City University Research Journal, Special Issue: AIC, 37-44. Retrieved from http://www.cusit.edu.pk/curj/Journals/Journal/special_aic_16/5.pdf

Mahmood, N., Jianfeng, C., Munir, H., \& Yasir, N. (2016). Impact of factors that inhibit the drive of entrepreneurship in Pakistan: Empirical evidence from young entrepreneurs and students. International Journal of $u$ - and e-Service, Science and Technology, 9(12), 163-174. http://dx.doi.org/10.14257/ijunesst.2016.9.12.15 
Miller, K., Alexander, A., Cunningham, J., \& Albats, E. (2018). Entrepreneurial academics and academic entrepreneurs: a systematic literature review. International Journal of Technology Management, 77 (1/2/3), 9-36.

http://dx.doi.org/10.1504/IJTM.2018.091710

Moreira, A. C., \& Carvalho, M. F. S. (2012). Incubation of new ideas: Extending incubation models to less-favored regions. Entrepreneurship-Creativity and Innovative Business Models. 41-58. https://doi.org/10.5772/36705

Oliveira, S. R. M. \& Vieira, M. T. (2016). Empirical evidence about the characteristics and business incubators performance: A framework of multiple cases. American International Journal of Contemporary Research, 6(1), 62-70. Retrieved from http://www.aijcrnet.com/journals/Vol_6_No_1_February_2016/6.pdf

O'Neal, T. (2005). Evolving a successful university-based incubator: Lessons learned from the UCF Technology Incubator. Engineering Management Journal, 17(3), 11-25. https://doi.org/10.1080/10429247.2005.11415293

Patton, D., Warren, L., \& Bream, D. (2009). Elements that underpin high-tech business incubation processes. Journal of Technology Transfer, 34(6), 621-636. https://doi.org/10.1007/s10961-009-9105-7

Pena, I. (2004). Business incubation centers and new firm growth in the Basque country. Small Business Economics, 22(3-4), 223-236. https://doi.org/10.1023/B:SBEJ.0000022221.03667.82

Perkmann, M., Tartarik, V., McKelvey, M., Autio, E., Broström, A., D’Este, P., \& Sobrero, M. (2013). Academic engagement and commercialisation: A review of the literature on university-industry relations. Research Policy, 42(2), 423-442. https://doi.org/10.1016/j.respol.2012.09.007

Peters, L., Rice, M., \& Sundararajan, M. (2004). The role of incubators in the entrepreneurial process. Journal of Technology Transfer, 29, 83-91. https://doi.org/10.1023/B:JOTT.0000011182.82350.df

Posza, A. (2019). Business incubation analysis with the help of real options theory. International Journal of Multidisciplinary in Business and Science, 5(8), 64-72. Retrieved from https://hrcak.srce.hr/228427

Queirós, A., Faria, D., \& Almeida, F. (2017). Strengths and limitations of qualitative and quantitative research methods. European Journal of Education Studies, 3(9), 369-387. https://doi.org/10.5281/zenodo.887089

Rahman, M. S. (2017). The advantages and disadvantages of using qualitative and quantitative approaches and methods in language "testing and assessment" research: A literature review. Journal of Education and Learning, 6(1), 102-112. http://dx.doi.org/10.5539/jel.v6n1p102 
Rashid, Y., Rashid, A., Akid, M., Warraich, A. M., Sabir, S. S., \& Waseem, A. (2019). Case study method: A step-by-step guide for business researchers. International Journal of Qualitative Methods, 18, 1-13. https://doi.org/10.1177/1609406919862424

Ratinho, T. (2011). Are they helping? An examination of business incubators' impact on tenant firms. [PhD dissertation, University of Twente, Portugal]. BMS Faculty: Dissertations Overview. https://doi.org/10.3990/1.9789036532631

Redondo, M. \& Camarero, C. (2017). Dominant logics and the manager's role in university business incubators. Journal of Business \& Industrial Marketing, 32(2), 282-294. https://doi.org/10.1108/JBIM-01-2016-0018

Schütte, M. C. (2019). Are dynamic capabilities relevant for incubation performance?. [Master's thesis, Lund University]. Lund University Libraries. https://doi.org/10.13140/RG.2.2.35139.76327

Schwartz, M. (2009). Beyond incubation: an analysis of firm survival and exit dynamics in the post-graduation period. The Journal of Technology Transfer, 34(4), 403-421. https://doi.org/10.1007/s10961-008-9095-x

Shane, S. \& Venkataraman, S. (2000). The promise of entrepreneurship as a field of research. Academy of Management Review, 25(1), 217-226. https://doi.org/10.2307/259271

Silva, F. M. G., \& Andrade Júnior, P. P. (2012). Incubadoras de empresas e o desenvolvimento econômico e tecnológico. Revista de Engenharia e Tecnologia, 4(3), 44-58. Retrieved from https://riuni.unisul.br

Smilor, R. W. (1987). Managing the incubator system: Critical success factors to accelerate new company development. IEEE Transactions on Engineering Management, 34(4),146-156. https://doi.org/10.1109/TEM.1987.6498875

Soetanto, D. P. (2004). Research of the role of the incubation policy in helping the growth of new technology based firms. Lisbon: Globelics Academy.

Sousa, J., Meneses, R., Ribeiro, H., \& Alves, S. R. (2018). The symbiotic relationship between startups and incubators. Article presented at the $36^{\text {th }}$ International Scientific Conference on Economic and Social Development - "Building Resilient Society" 2018, Zagreb, Croatia. Retrieved from https://www.esdconference.com/upload/book_of_proceedings/Book_of_Proceedings_esdZagreb2018_ Online.pdf

Stinchcombe, A. L. (2000). Social structure and organizations. Advances in Strategic Management, 17, 229-259. https://doi.org/10.1016/S0742-3322(00)17019-6

Stuart, T.E., \& Sorenson, O. (2003b). Liquidity events and the geographic distribution of entrepreneurial activity. Administrative Science Quarterly, 48, 175-201. https://doi.org/10.2307/3556656

Sukhur, S. S., \& Abu Bakar, S. (2018). Factors contributing to the incubation performance of Malaysian technology incubators. Economic and Technology Management Review, 13, 33-43. Retrieved from http://etmr.mardi.gov.my/Content/ETMR\%20Vol.13(2018)/Vol13_3.pdf 
Schwartz, M. (2009). Beyond incubation: an analysis of firm survival and exit dynamics in the post-graduation period. The Journal of Technology Transfer, 34(4), 403-421. https://doi.org/10.1007/s10961-008-9095-x

Schwartz, M. (2013). A control group study of incubators' impact to promote firm survival. Journal of Technology Transfer, 38, 302-331. https://doi.org/10.1007/s10961-0129254-y

Theodorakopoulos, N., Kakabadse, N., \& McGowan, C. (2014). What matters in business incubation? A literature review and a suggestion for situated theorising. Journal of Small Business and Enterprise Development, 21(4), 1-30. https://doi.org/10.1108/JSBED-09-2014-0152

Tsai, K. H. (2009). Collaborative networks and product innovation performance: Toward a contingency perspective. Research Policy, 38(5), 765-778. https://doi.org/10.1016/j.respol.2008.12.012

Van Burg, E. (2014). Commercializing science by means of university spin-offs: An ethical review. 346-369. https://doi.org/10.4337/9781781007020.00023

Verma, S. (2004). Success factors for business incubators: An empirical study of Canadian business incubators. [Master dissertation, Eric Sprott School of Business Carleton University Ottawa, Ontario]. Carleton University Research Virtual Environment. Retrieved from https://curve.carleton.ca/system/files/etd/3e53ae0a-1536-47fe-bf1561801227cbdf/etd_pdf/2897244706bf6a1a977d8a1b8c927d7a/vermasuccessfactorsforbusinessincubatorsanempirical.pdf

Walker, B. (2004). Selecting great clients: A Comprehensive Guide to Business Incubation [Completely Revised 2nd ed.]. National Business Incubation Association. Retrieved from https://inbia.org/wp-content/uploads/2018/07/Selecting-GreatClients.pdf?x62369

Wiggins, J., \& Gibson, D. (2003). Overview of US incubators and the case of the Austin technology incubator. International Journal of Entrepreneurship and Innovation Management, 3(1), 56-66. https://doi.org/10.1504/IJEIM.2003.002218

Wright, M., Piva, E., Mosey, S., \& Lockett, A. (2009). Academic entrepreneurship and business schools. Journal of Technology Transfer, 34(6), 560-587. https://doi.org/10.1007/s10961-009-9128-0

Wulung, R., Takahashi, K., \& Morikawa, K. (2014). An interactive multi-objective incubate selection model incorporating incubator manager orientation. Operational Research International Journal, 14, 409-438. https://doi.org/10.1007/s12351-014-0148-7

Yazan, B. (2015). Three approaches to case study methods in education: Yin, Merriam, and Stake. The Qualitative Report, 20, 134-152. https://doi.org/10.46743/21603715/2015.2102

Zaidan, O. F. (2014). R\&D universiti gagal tarik minat industri. Berita Harian. http://umkeprints.umk.edu.my/3239

Zikmund, W. G, (1997). Business Research Methods [5 $5^{\text {th }}$ edition]. Fort Worth, Texas: Dryden. Retrieved from https://www.amazon.com/gp/product/0030184320 


\section{Appendix}

1) What is your incubator structure?

- When was the incubator started?

- Where are you situated within the university structure?

- How large is your organisation?

- Can you explain your organisational structure?

- How many incubatees/incubated firms are under the incubator currently and since the establishment of the incubator?

- What are the sources of funding for the incubator?

- To what extent is this structure effective?

- Do you have accelerator programme?

2) How would you describe the purpose/scope of your incubator?

- Where is the focus area of your incubator?

- What kind of services does the incubator provide to fulfil the entrepreneur's skill requirement?

- What was the purpose to set up the incubator?

- To what extent has your incubator facilitated the entrepreneurial process?

3) Describe your incubation process.

- Who are the clients that you support?

- Describe your incubation process from selection to exit.

4) What are the indicators used to measure the success of the incubator?

- To what extent does it measure up to these indicators? Give reasons for this situation? 